\title{
Correction to: On the Nature of Ecological Paradox
}

\section{Correction to:}

\section{C. Tobias, J. G. Morrison, On the Nature of Ecological}

Paradox, https://doi.org/10.1007/978-3-030-64526-7

"This book was inadvertently published without incorporating the below corrections, and these corrections have now been incorporated in the book"

- On page 792, caption of Fig. 90.4 was updated to: Martin Buber (1878-1965), Public Domain.

- On page 437, caption of Fig. 47.3 was updated to: Rembrandt's Mother, Neeltgen Willemsdochter van Zuytbrouck (1569-1640), painted by Rembrandt. Private Collection.

- On page 557, Fig. 59.3 was revised with a new image and the caption was updated to: Engraving of a Floating Castle (Detail), a Mythologized Kingdom of Human/Landscape Interactions such as was Enshrined by Kings and Emperors like Rudolf II, By David Vinckboons, Engraver Nicolaes de Bruyn, 1601. (Private Collection). (Photo (C) M.C. Tobias)

- On Page xxvii/xxviii, Jane Gray Morrison’s biography was updated.

- The back cover text was updated.

The updated online versions of the chapters can be found at https://doi.org/10.1007/978-3-030-64526-7 https://doi.org/10.1007/978-3-030-64526-7_47 https://doi.org/10.1007/978-3-030-64526-7_59

https://doi.org/10.1007/978-3-030-64526-7_90 